\title{
Production and characterization of $\beta$-galactosidase from the fungus Thielaviopsis ethacetica Went.
}

\author{
DMS Dissanayaka ${ }^{1}$, SNT De Silva ${ }^{2 *}$, DPSTG Attanayaka ${ }^{1}$ and EMM Vimukthi ${ }^{1}$ \\ ${ }^{I}$ Department of Biotechnology, Faculty of Agriculture and Plantation Management, Wayamba University of Sri Lanka, Makandura, Gonawila. \\ ${ }^{2}$ Department of Material and NanoScience Technology, Faculty of Technology, Wayamba University of Sri Lanka, Kuliyapitiya.
}

Submitted: 14 December 2020; Revised: 24 May 2021; Accepted: 03 August 2021

\begin{abstract}
EC 3.2.1.23) is an industrially important enzyme. It can catalyse two different types of reactions, namely lactose hydrolysis and transgalactosylation. $\beta$-galactosidase enzyme production by Thielaviopsis ethacetica, was investigated and the enzyme was partially purified and characterized in the present study. Qualitative assay for the pre $\beta$-galactosidase activity indicated the formation of water insoluble blue-green colour, dichloro-dibromo-indigo zone towards the edges of the fungal colony after a 72-hour incubation period. Quantitative assay recorded a maximum enzyme activity of $0.599 \mathrm{U} / \mathrm{mL}$ at 72 hours. The enzyme was partially purified from the crude enzyme using ammonium sulphate precipitation and dialysis. Fraction 40-60\% (fraction 2 ) had the highest specific enzymes activity of $1.65 \mathrm{U} / \mathrm{mg}$ with 8.68 purification fold and $28.3 \%$ recovery. SDS-PAGE analysis of fraction 2 resulted three separate protein bands above $40 \mathrm{kDa}$. The protein band corresponding to $50 \mathrm{kDa}$ molecular weight was confirmed as $\beta$-galactosidase. The optimum temperature and $\mathrm{pH}$ for the enzyme was at $60^{\circ} \mathrm{C}$ and 7.0 , respectively. The present study reveals the fungal strain Thielaviopsis ethacetica with $\beta$-galactosidase activity. To our knowledge this is the first report about $\beta$-galactosidase activity of the strain $T$. ethacetica. This investigation suggests the potential use of this species in industrial applications.
\end{abstract}

Keywords: $\beta$-galactosidase, industrial enzyme, MALDI/MS, starch hydrolysis, Thielaviopsis ethacetica.

\section{INTRODUCTION}

$\beta$-galactosidase (EC 3. 2. 1. 23), also known as $\beta$-Dgalactohydrolase, $\beta$-D-galactoside galactohydrolase, galactosyltransferase or lactase is an enzyme that has a wide range of applications in the industrial sector. It catalyses two different reactions in organisms: the hydrolyzation of lactose into glucose and galactose (Akcan, 2011), and transgalactosylation reaction which synthesizes important prebiotics such as lactulose and galacto-oligosaccharides (GOS) (Lu et al., 2009). These prebiotics have numerous health benefits and thus $\beta$-galactosidase has high demand in both food (Mahoney \& Adamchuk, 1980; Jokar \& Karbassi, 2009; Princely et al., 2013; Klein et al., 2016; Saqib et al., 2017) and dairy industries (He et al., 2007; Pal et al., 2013; Erich et al., 2015).

$\beta$-galactosidases are widely distributed in different biological systems, e.g. microorganisms, plants such as almonds, peaches, apricots, and animal tissues such as brain and placenta (Kayukawa et al., 2020). $\beta$-galactosidases are members of the family of hydrolases that belongs to the group of saccharide-converting enzymes. Properties, activity and the structure of the enzyme such as position of the active site, molecular weight of the enzyme, length of the amino acid chain, thermal and $\mathrm{pH}$ stability vary with the sources from which the enzyme is obtained (Zhou \& Chen, 2001). Therefore, source of the enzyme can be selected according to one's choice, depending on reaction conditions. Among all the natural sources, production of the enzyme is focused on microorganisms as they have the ability to grow on low-cost substrates. Moreover, compared to plants and

\footnotetext{
*Corresponding author (nimalides@wyb.ac.lk; (iD https://orcid.org/0000-0002-4481-4247)
} 
animal sources, higher yields can be obtained while minimizing the cost of production (Santos et al., 1998). Microorganisms including yeast, fungi, bacteria and actinomycetes have been exploited for $\beta$-galactosidase production (Zadow, 1992; Fernandez, 1999; Bhanwar \& Ganguli, 2014; Panesar et al., 2016; Xu et al., 2019). Among these microorganisms special attention is still paid to fungal sources as their enzymes are thermostable. Since the enzyme is extracellular, additional cost for the extraction is very low. Furthermore, fungi give higher yields, and their enzymes show broad stability profiles. Therefore, the commercially available $\beta$-galactosidases have been mainly obtained from fungi: yeast and moulds. The most important sources are Aspergillus and Kluyveromyces species including A. oryzae, K. lactis, K. marxianus and K. fragilis (Zhou \&d Chen, 2001; Roy \& Gupta, 2003; Johnson \& Echavarri-Erasun, 2011; Maccaferri et al., 2012; Martarello et al., 2019). As the demand is high, finding new fungal source for the production of the enzyme is of current interest.

The objective of the present study was the optimisation of production, partial purification and characterisation of $\beta$-galactosidase secreted by Thielaviopsis ethacetica.

\section{METHODOLOGY}

\section{The microorganism and culture conditions}

Fungal strain Thielaviopsis ethacetica has been previously isolated from the topsoil and identified to exhibit alpha-amylase activity (Dissanayaka et al., 2019). The internal transcribed spacer (ITS) sequences have been deposited in the GenBank/NCBI (Accession no; MG062870.1). The fungus was stored in potato dextrose agar (PDA) slants for long term storage and subcultures were prepared once a month throughout the study period. After reviving on PDA supplemented with tetracycline, spores were picked up using a sterile moistened loop and streaked on to $2 \%$ sterile agar plates and incubated at $26{ }^{\circ} \mathrm{C}$ for $18 \mathrm{~h}$. Germinated spores were transferred aseptically onto fresh PDA plates to get a single spore culture.

\section{Qualitative assay for the pre $\beta$-galactosidase activity}

To observe the pre $\beta$-galactosidase activity, $6 \mathrm{~mm}$ diameter disc of mycelium cut from the growing edge of fungal colonies were transferred aseptically onto YpSs agar plates (2\% agar, $0.4 \%$ yeast extract, $0.05 \%$ $\mathrm{MgSO}_{4} 7 \mathrm{H}_{2} \mathrm{O}, 0.1 \% \mathrm{KH}_{2} \mathrm{PO}_{4}$, and $1.5 \%$ soluble starch), supplemented with $80 \mu \mathrm{g} / \mathrm{mL}$ X-gal (5-bromo-4-chloro- 3-indolyl- $\beta$-D-galactoside) (Sigma). The plates were incubated at $32{ }^{\circ} \mathrm{C}$ for $72 \mathrm{~h}$ and the observations were made at every 24-hour intervals. In the presence of $\beta$-galactosidase enzyme, $X$-Gal would be cleaved at the $\beta-1-4$ bond between galactose and the 5-bromo-4-chloro3 -indolyl part of X-Gal producing a blue-green colour formation in culture plates.

\section{Determining the time for optimal enzyme production}

Pre-inoculum was prepared in $50 \mathrm{~mL}$ of fermentation medium comprising $2 \%$ soluble starch, $0.5 \%$ yeast extract, $0.03 \% \mathrm{MgSO}_{4}, 0.03 \% \mathrm{CaCl}_{2}$ and $0.7 \% \mathrm{KH}_{2} \mathrm{PO}_{4}$ at $\mathrm{pH}$ 4. Sterile medium was inoculated with 3 agar plugs of profusely growing fungi (6 $\mathrm{mm}$ diameter) and incubated at room temperature with shaking at $120 \mathrm{rpm}$. After 96 hours of incubation, $5 \mathrm{~mL}$ of homogenized pre-inoculum $\left(5 \times 10^{4}-6 \times 10^{4}\right.$ spore $\left./ \mathrm{mL}\right)$ was carefully withdrawn and added to $50 \mathrm{~mL}$ of the fermentation medium.

Fermentation medium was incubated at $32^{\circ} \mathrm{C}$ for $72 \mathrm{~h}$ in a rotary shaker at $120 \mathrm{rpm}$ (Dissanayaka et al., 2019). $\beta$-galactosidase activity and total protein concentration was measured at 12 -hour intervals by removing $150 \mu \mathrm{L}$ from the fermentation medium. All assays were carried out in triplicate.

\section{$\beta$-galactosidase enzyme assay}

$\beta$-galactosidase activity on soluble starch was assayed by using o-nitrophenol-galactopyranoside (o-NPG) (Miller, 1972).

Appropriately diluted $0.15 \mathrm{~mL}$ crude enzyme was mixed with $0.6 \mathrm{~mL}$ of substrate solution. $1 \mathrm{mM}$ o-NPG was prepared in $0.1 \mathrm{M}$ sodium phosphate buffer at $\mathrm{pH}$ 7.0. The reaction mixture was incubated at $40{ }^{\circ} \mathrm{C}$ for $30 \mathrm{~min}$. The reaction was terminated by adding $1 \mathrm{~mL}$ of $1 \mathrm{~m}$ of $\mathrm{Na}_{2} \mathrm{CO}_{3}$. The concentration of o-nitrophenol (oNP) released from o-NPG was determined by measuring the absorbance at $420 \mathrm{~nm}$ by UV spectrophotometer using the standard calibration curve (Soydan, 2006; Konsoula \& Liakopoulou-Kyriakides, 2007). For enzyme blank, 0.15 $\mathrm{mL}$ of sample was mixed with $0.6 \mathrm{~mL}$ of buffer and $1 \mathrm{~mL}$ of $1 \mathrm{M} \mathrm{Na}_{2} \mathrm{CO}_{3}$. For substrate blank, $0.15 \mathrm{~mL}$ of buffer was mixed with $0.6 \mathrm{~mL}$ of substrate solution and $1 \mathrm{~mL}$ of $1 \mathrm{M} \mathrm{Na}_{2} \mathrm{CO}_{3}$. Mean absorbance value of the triplicates was taken to calculate the unit enzyme activity. One unit of $\beta$-galactosidase activity was defined as the amount of enzyme required to release $1 \mu \mathrm{mol}$ o-nitrophenol per minute under assay conditions (Soydan, 2006, Konsoula \& Liakopoulou-Kyriakides, 2007). 


\section{Total protein content assay}

Total protein concentration was assayed in triplicate using Qubit 3 Invitrogen $^{\mathrm{TM}}$ Qubit $^{\mathrm{TM}} 3.0$ Fluorometer according to the given instructions in Qubit assay kit (Invitrogen ${ }^{\mathrm{TM}}$ ).

\section{Partial purification of the $\beta$-galactosidase enzyme}

Five hundred millilitres from the submerged fermentation medium containing $2 \%$ soluble starch were inoculated with the fungal strain Thielaviopsis ethacetica and incubated at $32{ }^{\circ} \mathrm{C}$ for $72 \mathrm{~h}$. After the incubation, culture medium was centrifuged at $6000 \mathrm{rpm}$ for $15 \mathrm{~min}$ at $40{ }^{\circ} \mathrm{C}$ and the supernatant was subjected to gradient ammonium sulphate fractionation. The supernatant was brought into $40 \%$ (Fraction 1) saturation followed by $60 \%$ (Fraction 2), 80\% (Fraction 3), and 100\% (Fraction 4). Ammonium sulphate was gradually added into the medium while stirring continuously using a magnetic stirrer (Wingfield, 2001). Saturated protein samples were then centrifuged at $12000 \mathrm{rpm}$ for $15 \mathrm{~min}$, at $40{ }^{\circ} \mathrm{C}$ and the protein pellets were recovered. Before the dialysis, each pellet was dissolved in a minimum volume of $0.1 \mathrm{M}$ phosphate buffer at $\mathrm{pH} 7$ separately. Dialysis was accompanied by continuous stirring over 24 hours at $40{ }^{\circ} \mathrm{C}$ against the same buffer and the buffer was changed intermittently. Finally, all the fractions were assayed for enzyme activity and total protein concentration.

Investigation the effect of temperature on $\beta$-galactosidase activity

To find the effect of temperature and $\mathrm{pH}$ on $\beta$-galactosidase activity, Fraction 2 (40-60\%) with the highest enzyme activity was collected and used. The effect of temperature was evaluated at $20,37,40,60$ and $80{ }^{\circ} \mathrm{C}$ by incubating the reaction mixture for $30 \mathrm{~min}$. $\beta$-galactosidase enzyme activity was determined as previously described.

\section{Investigation of the effect of $\mathrm{pH}$ on $\beta$-galactosidase activity}

The effect of $\mathrm{pH}$ on enzyme activity was evaluated by adjusting the $\mathrm{pH}$ of the substrate at $4,5,6,7$, and 8 . The reaction mixture was incubated at $60{ }^{\circ} \mathrm{C}$ for $30 \mathrm{~min}$ under specific $\mathrm{pH}$ value and enzyme activity was determined as previously described.

\section{Determination of the molecular weight of Thielaviopsis ethacetica $\beta$-galactosidase}

Partially purified protein fraction 2 with the highest enzyme activity was freeze-dried (CHRIST Alpha 1-2
LDplus, Germany) and $1 \mathrm{mg}$ of lyophilized protein sample was dissolved in an appropriate volume of sample buffer (Laemmli, 1970). To separate proteins in the sample, $10 \%$ sodium dodecyl sulfate polyacrylamide gel (SDS-PAGE) stained with Coomassie Brilliant Blue R-250 was used. To determine the molecular weight of the protein, a broad range molecular weight protein marker ranging from $10-100 \mathrm{kDa}$ was used.

\section{Protein identification using mass spectrometry peptide sequencing (MALDI/MS) method}

Molecular weight of many fungal $\beta$-galactosidases lies around $40-75 \mathrm{kDa}$. Therefore, three separated protein bands representing more than $40 \mathrm{kDa}$ were used for MALDI/MS identification. Immediate gel surface around these three bands were carefully separated and stored in an appropriate amount of sterilized distilled water. Three protein samples were sent to ALPHALYSE, Denmark for protein identification using Bruker Autoflex Speed MALDI TOF/TOF instrument. The resulted spectra were searched against available protein databases from UniProtKB using the Mascot software.

\section{RESULTS AND DISCUSSION}

\section{Qualitative assay for the pre $\beta$-galactosidase activity}

Although X-Gal is a commonly associated colourimetric method with lac operon in E. coli, the applicability of $\mathrm{X}$-Gal for the detection of fungal $\beta$-galactosidase is still under assessment. In the present study, it has been attempted to determine the presence of an active fungal $\beta$-galactosidase in culture plates containing X-Gal. IPTG was not added to the culture plates as an inducer. After a 72-hour incubation period, a blue-green colour zone formation was observed towards the edges of the fungal colony. A similar finding has been reported by Fischer et al. (1995a), Soydan (2006), and Kishore and Kayastha (2012) with fungal $\beta$-galactosidase enzyme. This method will be a great advantage during the early screening procedures when the number of testing samples are high.

\section{$\beta$-galactosidase enzyme assay}

Thielaviopsis ethacetica containing fermentation medium gave a prominent peak for $\beta$-galactosidase enzyme activity during the $3^{\text {rd }}$ day of the incubation. During the first 24 hours protein concentration gradually increased and then peaked at 48 hours $(184.2 \mu \mathrm{g} / \mathrm{mL})$, where $\beta$-galactosidase enzyme activity remained in lower points until $36 \mathrm{~h}$. After 36 hours, enzyme activity 
gradually increased reaching its maximum at 72 hours giving $0.599 \mathrm{U} / \mathrm{mL}$ maxima with a simultaneous drop in protein content to $67 \mu \mathrm{g} / \mathrm{mL}$ (Figure 1). After 72 hours, enzyme activity remained static where the protein concentration started to increase. Static enzyme activity may probably be due to the denaturation of protein resulted from unfavourable culture conditions during the latter part of the incubation period. Moreover, due to the depletion of initial substrate concentration, newly synthesised mycelia may be secreting other proteins extracellularly to degrade substrates other than starch, resulting in an increased protein concentration after 72 hours.

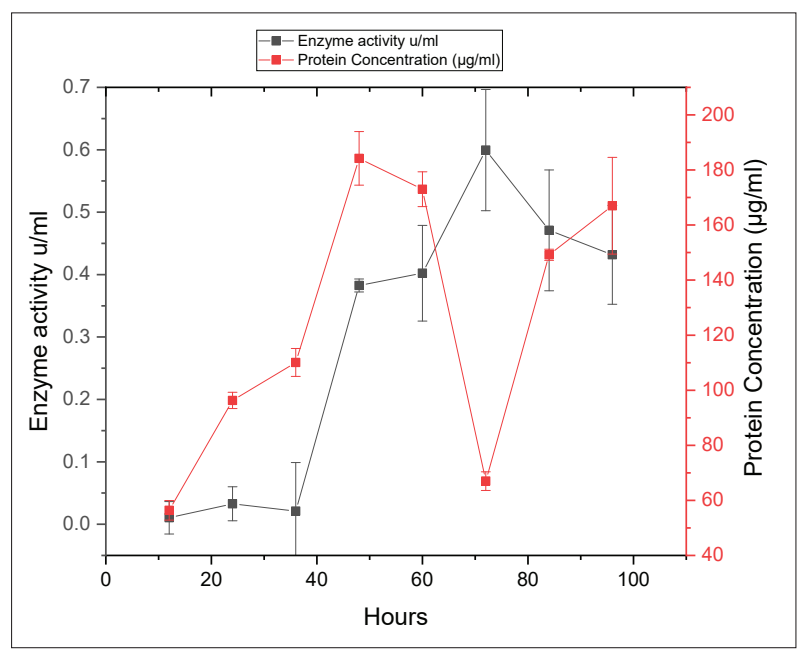

Figure 1: Total protein content and enzyme activity against incubation time. Error bars represents standard deviation

Optimum $\beta$-galactosidase enzyme activity was observed at 72 hours incubation period. Therefore, the extraction of $\beta$-galactosidase from $T$. ethacetica was fixed to 72 hours of incubation period. Late secretion of $\beta$-galactosidase enzyme was observed in many other organisms; for example, Bacillus sp., Rhizomucor sp. and Aspergillus sp. (Shaikh et al., 1997; Akcan, 2011; Martarello et al., 2019). Quantitative determination of the $\beta$-galactosidase activity is commonly accomplished by using colourimetric method. $\beta$-galactosidase is capable of catalysing substrates with b-D-galactopyranoside residues like o-nitrophenol-galactopyranoside (o-NPG). During the hydrolysing process it can form galactose and o-nitrophenol (oNP) with a yellow colour. oNP is capable of absorbing light at $420 \mathrm{~nm}$, therefore the colour intensity can be used to detect $\beta$-galactosidase activity of complex biological systems (Miller, 1972).

The present study used starch as the substrate, instead of well-known $\beta$-galactosidase substrates containing b-Dgalactopyranoside moiety or lactose. The results suggest that one of the intermediate or an end product such as maltose or malto dextrin produced during the starch hydrolysis may act as the substrate for $\beta$-galactosidase enzyme production. Konsoula and LiakopoulouKyriakides (2007) reported that there can be about 1.5 fold increament of $\beta$-galactosidase enzyme activity when using soluble starch as the fermentation medium instead of lactose under the co-production culture conditions of alpha-amylase enzyme. Further, it has been reported that the enzyme production is induced in the presence of yeast extract (Konsoula \& Liakopoulou-Kyriakides, 2007). Nitrogen dependancy and carbon independancy of $\beta$ - galactosidase have opened many arguments among the scientific community and still there is no strong conclusion regading its substrate specificity (Lind et al., 1989; Fischer et al, 1995; Konsoula \& Liakopouloukyriakides, 2007).

Table 1: Enzyme activity and total protein content of ammonium sulphate fractions

\begin{tabular}{cccccc}
\hline $\begin{array}{c}\text { Ammonium sulphate } \\
\text { percentage }\end{array}$ & $\begin{array}{c}\text { Total enzyme } \\
\text { activity }(\mathrm{u} / \mathrm{mL})\end{array}$ & $\begin{array}{c}\text { Total protein } \\
\text { content }(\mathrm{mg})\end{array}$ & $\begin{array}{c}\text { Specific activity } \\
(\mathrm{u} / \mathrm{mg})\end{array}$ & $\begin{array}{c}\text { Purification } \\
\text { fold }\end{array}$ & $\begin{array}{c}\text { Recovery } \\
(\%)\end{array}$ \\
\hline Crude & 8.75 & 45 & 0.19 & 1 & 100 \\
$0-40 \%$ & 1.15 & 1.83 & 0.63 & 3.31 & 13.1 \\
$40-60 \%$ & $2.475^{* *}$ & 1.5 & 1.65 & 8.68 & 28.3 \\
$60-80 \%$ & 1.776 & 1.25 & 1.42 & 7.47 & 20.3 \\
$80-100 \%$ & 0.860 & 0.84 & 1.02 & 5.37 & 9.8 \\
\hline
\end{tabular}

$0-40 \%$ (fraction 1); $40-60 \%$ (fraction 2); 60-80\% (fraction 3); 80-100 \% (fraction 4)

** Indicates the highest enzyme activity for fraction 2 


\section{Partial purification of the $\beta$-galactosidase enzyme}

During the partial purification of $\beta$-galactosidase, initially, the culture supernatant was saturated with ammonium sulphate from $0-40 \%$ (Fraction 1), 40-60\% (Fraction 2), 60-80\% (Fraction 3) and 80-100\% (Fraction 4). Out of the four fractions, fraction 2 had the highest specific enzymes activity of $1.65 \mathrm{U} / \mathrm{mg}$ with an 8.68 purification fold and $28.28 \%$ recovery (Table 1 ). Therefore, Fraction 2 was selected for further assay.

\section{Effect of temperature on $\beta$-galactosidase activity}

Under the defined assay conditions maximum temperature for $\beta$-galactosidase enzyme activity was determined at temperatures ranging from $20-80^{\circ} \mathrm{C}$. The optimum temperature for maximum $T$. ethacetica $\beta$-galactosidase activity was found to be around $60{ }^{\circ} \mathrm{C}$ (Figure 2). Many researchers have reported an optimum temperature around $60{ }^{\circ} \mathrm{C}$ for Aspergillus oryzae, A. niger, A. carbonarius, A. fonsecaeus, Rhizomucor sp., Mucor sp. and Fusarium sp. (Sorensen \& Crisan, 1974; Park et al., 1979; Gonzalez \& Monsan, 1991; Shaikh et al., 1997; O'Connell \& Walsh, 2008; Martarello et al., 2019).

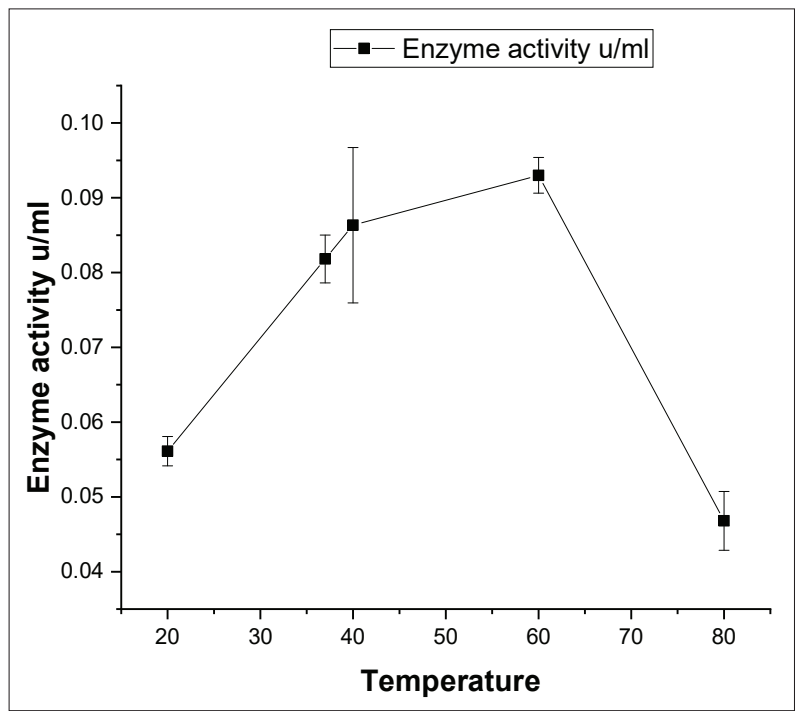

Figure 2: Variation of activity of purified enzyme from fraction 2 with temperature at $\mathrm{pH}$ 7.0. Error bars represent standard deviation

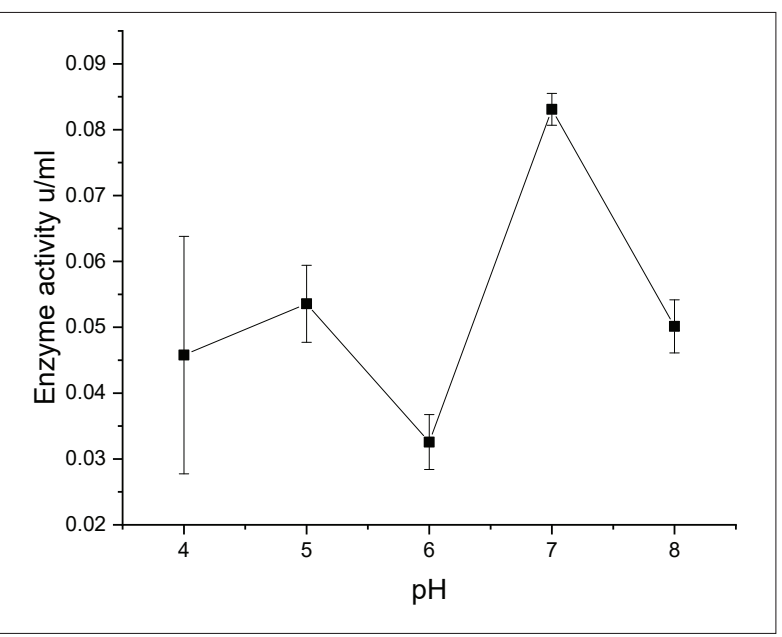

Figure 3: Variation of activity of partially purified enzyme from fraction 2 with $\mathrm{pH}$ at $60^{\circ} \mathrm{C}$. Error Bars represent standard deviation

\section{Effect of pH on $\beta$-galactosidase activity}

Thielaviopsis ethacetica exhibited two prominent enzyme activity peaks for $\beta$-galactosidases at distinct $\mathrm{pH}$ values. The highest activity peak with $0.083 \mathrm{U} / \mathrm{mL}$ was observed at $\mathrm{pH} 7$ and slightly lower second peak of $0.054 \mathrm{U} / \mathrm{mL}$ at $\mathrm{pH} 5$ (Figure 3).

These results show similarities to the observations made by Fisher et al. (1995) for Thermomyes sp. In the literature it is reported that most fungal $\beta$-galactosidase showed high activity in two $\mathrm{pH}$ ranges from 3-5 and 6-7. Borglum and Sternberg (1972), Cardoso et al. (2017), Gekas and Lopez-Leiva (1985), Niu et al. (2017), and O'Connell and Walsh (2008) reported that most of the Aspergillus and Mucor species exhibited enhanced enzyme activity under low $\mathrm{pH}$ values. On the other hand, Đfrij and Ögel (2002), Fischer et al. (1995), Martarello et al. (2019) and Matioli et al. (2001) reported that the highest enzyme activity was near neutral $\mathrm{pH}$ with Aspergillus, Thermomyces and Kluyveromyces species. However, due to having two enzyme activity peaks in the acidic and neutral $\mathrm{pH}$ ranges, the present strain can give an additional advantage for use in industry. Considering the acid stability nature of the enzyme, it can be useful in the pharmaceutical industry, while its activity near neutral $\mathrm{pH}$ values can be useful in the dairy industry. 


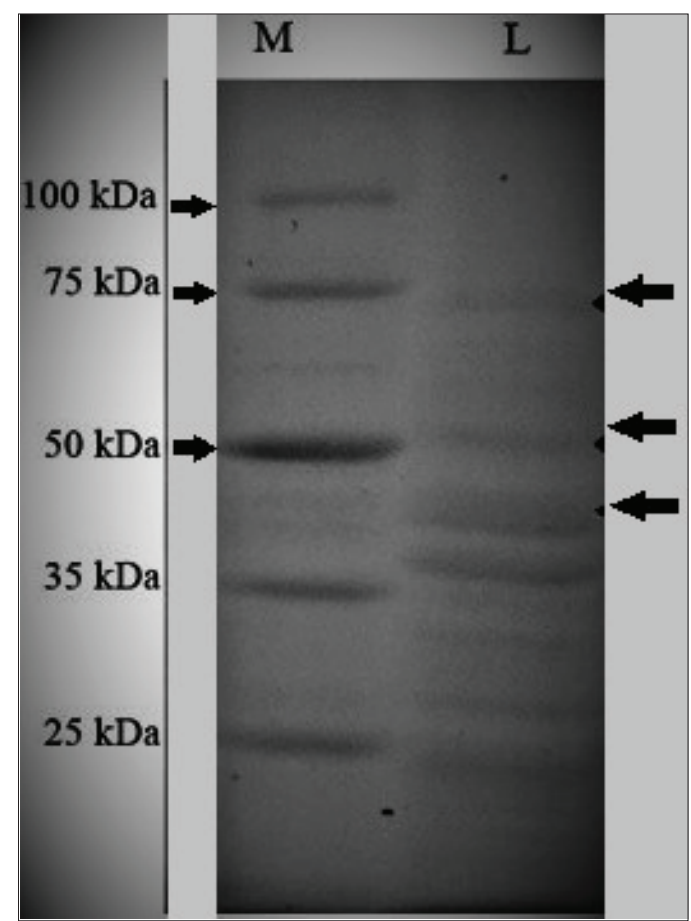

Figure 4: Image of SDS-PAGE (fraction 2). Arrows indicate three protein bands used for MALDI/ MS identification. (M) molecular marker; (L) protein profile of the T. ethacetica

\section{Determination of the molecular weight of $T$. ethacetica $\beta$-galactosidase}

Partially purified lyophilised fraction 2 was run with a marker protein in SDS-PAGE. The resulted gel image is given in Figure 4. Three proteins bands designated by arrows were used for MALDI-MS/MS identification. MALDI-MS/MS analysis involved 15 partially sequenced peptides and identity searching against UniProtKB using Mascot software. The protein band corresponded to $50 \mathrm{kDa}$ molecular weight was matched to E. coli $\beta$-galactosidase with 729 Mascot score value ( $>95 \%$ confidence level). Identified peptides corresponding to $E$. coli $\beta$-galactosidase are shown in Figure 5 with $25 \%$ sequence coverage. MALDI/MS peptide mapping and sequencing permit the identification of peptide sequences in a mixture especially when it is difficult to obtain one single pure protein. During the SDS-PAGE, Coomassie Brilliant Blue R-250 was used for staining to minimize the interference during mass spectrometry. According to available data on the molecular weight summary report on $\beta$-galactosidase, its molecular weight can range from $12 \mathrm{kDa}$ to $270 \mathrm{kDa}$ depending on the species from which it has been isolated. $\beta$-galactosidase isolated from Thermomyces and Thermotoganaphthophila species had molecular weights between 75-80 kDa (Fischer et al., 1995) and $70 \mathrm{kDa}$ (Kong et al., 2014), respectively, whereas the enzyme

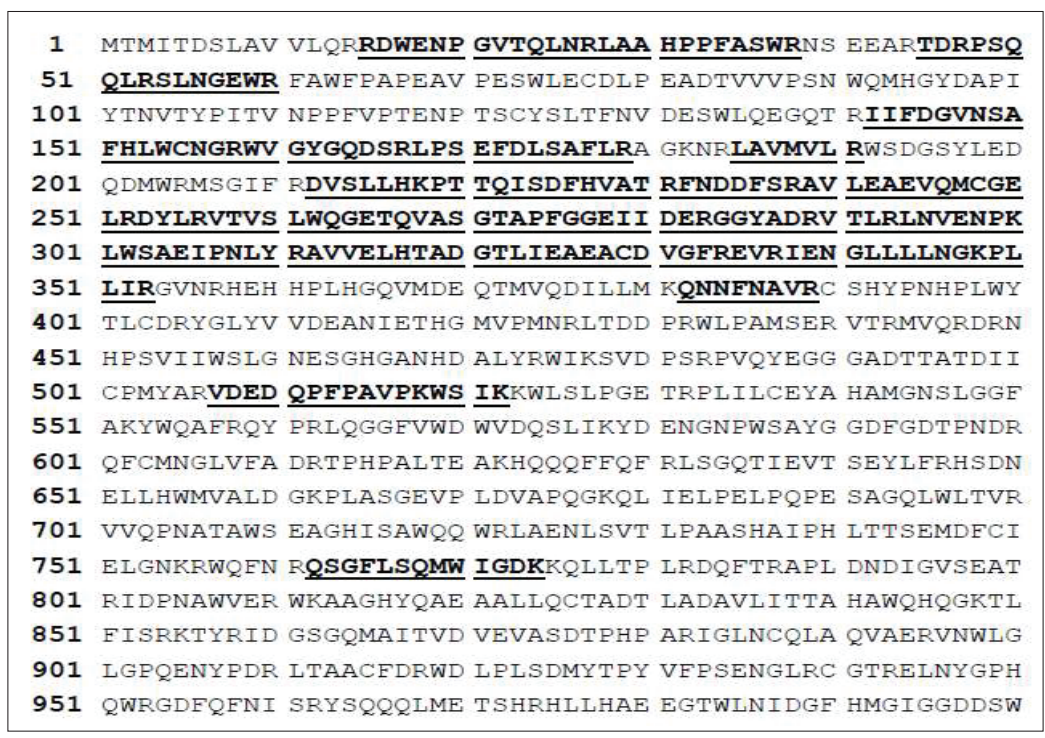

Figure 5: Partial amino acid sequences of protein band correspond $50 \mathrm{kDa}$ molecular weight of $T$. ethacetica matched to E. coli $\beta$-galactosidase enzyme. Mapped peptides are shown in bold. 729 Mascot score value ( $>95 \%$ confidence level). 
of Aspergillus species reported to have a molecular weight range of 27-126 kDa (Tanaka et al., 1975; Park et al., 1979; Gonzalez \& Monsan, 1991; Saad, 2004; Todorova-Balvay et al., 2006). Considering the results of the protein sequencing analysis of the present study, it is indicated that majority of the starch hydrolase at 72 hours represent $\beta$-galactosidase enzyme.

\section{CONCLUSION}

The present study identified a fungal strain Thielaviopsis ethacetica with $\beta$-galactosidase activity and to the best of our knowledge this is the first report on $\beta$-galactosidase activity by $T$. ethacetica. Enzyme activity at high temperature, $\mathrm{pH}$ preference and substrate independency make the $\beta$-galactosidase produced by this strain suitable for industrial applications. Further, we emphasize the coproduction ability of alpha amylase and $\beta$-galactosidase under starch fermentation medium, which can be readily substituted with low-cost substrates such as rice bran, banana peel and cassava starch (Dissanayaka et al., 2019). During the initial stages of growth, $T$. ethacetica secretes extracellular alpha-amylase to the medium and involves starch hydrolysing process. Subsequently, it begins and continues to secrete $\beta$-galactosidase up to its death phase. Fungal strains having such beneficial enzyme production characteristics would have a significant impact on industrial-scale applications. Therefore, new opportunities exist for further research on enzyme production abilities of $T$. ethacetica and optimization of such capabilities to fulfil the industrial demands on starch processing.

\section{Conflict of interest statement}

The authors declare that they have no known competing financial interests or personal relationships that could have appeared to influence the work reported in this paper.

\section{Acknowledgement}

Authors wish to gratefully acknowledge the financial assistance provided by the National Science Foundation of Sri Lanka (NSF grant Number RG/2016/BT/01).

\section{REFERENCES}

Akcan N. (2011). High level production of extracellular $\beta$-galactosidase from Bacillus licheniformis ATCC 12759 in submerged fermentation. African Journal of Microbiology Research 5(26): 4615-4621.

DOI: https://doi.org/10.5897 /AJMR11.716
Bhanwar S. \& Ganguli A. (2014). Alpha-amylase and $\beta$-galactosidase production on potato starch waste by Lactococcus lactis subsp lactis isolated from pickled yam. Jounal of Acientific and Industrial Research 73(5): 324-330.

Borglum G.B. \& Sternberg M.Z. (1972). Properties of a fungal lactase. Journal of Food Science 37: 619-623.

Cardoso B.B., Silvério S.C., Abrunhosa L., Teixeira J.A. \& Rodrigues L.R. (2017). $\beta$-galactosidase from Aspergillus lacticoffeatus: A promising biocatalyst for the synthesis of novel prebiotics. International Jounal of Food Microbiology 257: 67-74.

DOI: https://doi.org/10.1016/j.ijfoodmicro.2017.06.013

Đfrij Đ.H. \& Ögel Z. (2002). Production of neutral and alkaline proteases by the thermophilic fungus Scytalidium thermophilum, grown on microcrystaline cellulose. Biotechnology Letters 24: 1107-1110.

Dissanayaka D.M.S., De Silva S.N.T., Attanayaka D.P.S.T.G., Kurera M.J.M.S. \& Fernando C.A.N. (2019). Characterization of alpha amylase producing Thielaviopsis ethacetica and its raw starch hydrolyzing ability on different agricultural substrates. Microbiology and Biotechnology Letters 47(3) : 412-422.

DOI: https://doi.org/10. 4014/mbl.1812.12002

Erich S., Kuschel B., Schwarz T., Ewert J., Bohmer N., Niehaus F., Eck J., Lutz-Wahl S., Stressler T. \& Fischer L. (2015). Novel high-performance metagenome $\beta$-galactosidases for lactose hydrolysis in the dairy industry. Journal of Biotechnology 210: 27-37.

DOI: https://doi.org/10.1016/j.jbiotec.2015.06.411

Fernandez M. (1999). Duplication of the $\beta$-galactosidase gene in some Lactobacillus plantarum strains. International Journal of Food Microbiology 48(2): 113-123. DOI: https://doi.org/10.1016/S0168-1605(99)00031-8

Fischer L., Scheckermann C. \& Wagner F. (1995). Purification and characterization of a thermotolerant $\beta$-galactosidase from Thermomyces lanuginosus. Applied and Environmental Microbiology 61(4): 1497-1501. DOI: https://doi.org/10.1128/AEM.61.4.1497-1501.1995

Gekas V. \& Lopez-Leiva M. (1985). Hydrolysis of lactose: a literature review. Process Biochemistry 20: 2-11.

Gonzalez R.R. \& Monsan P. (1991). Purification and some characteristics of $\beta$-galactosidase from Aspergillus fonsecaeus. Enzyme and Microbial Technology 13: 349352.

He T., Priebe M.G., Zhong Y., Huang C.,Harmsen H.J.M., Raangs G.C., Antoine J.M., Welling G.W. \& Yonk R.J. (2007). Effects of yogurt and bifidobacteria supplementation on the colonic microbiota in lactose-intolerant subjects. Journal of Applied Microbiology 104(2): 595-604. DOI: https://doi.org/10.1111/j.1365-2672.2007.03579.x

Johnson E.A. \& Echavarri-Erasun C. (2011). Yeast biotechnology. In: The Yeasts (eds. C.P. Kurtzman, J.W. Fell \& T. Boekhout), $5^{\text {th }}$ edition, pp. 21-44. Elsevier, Netherlands.

DOI: https://doi.org/10.1016/B978-0-444-52149-1.00003-3

Jokar A. \& Karbassi A. (2009). Determination of proper conditions for the production of crude $\beta$-galactosidase 
using Lactobacillus delbrueckii ssp. Bulgaricus. Journal of Agricultural Science and Technology 11(3). 301-308.

Kayukawa C.T.M., Oliveira M.A.S., Kaspchak E., Sanchuki H.B.S., Igarashi-Mafra L. \& Mafra M.R. (2020). Quillaja bark saponin effects on Kluyveromyces lactis $\beta$-galactosidase activity and structure. Food Chemistry 303: 125388.

DOI: https://doi.org/10.1016/j.foodchem.2019.125388

Kishore D. \& Kayastha A.M. (2012). A $\beta$-galactosidase from chick pea (Cicer arietinum) seeds: Its purification, biochemical properties and industrial applications. Food Chemistry 134(2): 1113-1122.

DOI: https://doi.org/10.1016/j. foodc hem.2012.03.032

Klein M.P., Hackenhaar C.R, Lorenzoni A.S.G., Rodrigues R.C., Costa M.H., Ninow J.L. \& Hertz P.F. (2016). Chitosan crosslinked with genipin as support matrix for application in food process: Support characterization and $\beta$-D-galactosidase immobilization. Carbohydrate Polymers 137: 184-190.

DOI: https://doi.org/10.1016/j.carbpol.2015.10.069

Kong F., Yeging W., Shugui C., Renjun G. \& Guigiu X. (2014). Cloning, purification and characterization of a thermostable $\beta$-galactosidase from Thermotoga naphthophila RUK-10. Process Biochemistry 49: 775-782.

Konsoula Z. \& Liakopoulou-Kyriakides M. (2007). Coproduction of $\alpha$-amylase and $\beta$-galactosidase by Bacillus subtilis in complex organic substrates. Bioresource Technology 98(1): 150-157.

DOI: https://doi.org/10.1016/j. biortech.2005.11.001

Laemmli U.K. (1970). Cleavage of structural proteins during the assembly of the head of bacteriophage T4. Nature 227: $680-685$.

Lind D.L., Daniel R.M., Cowan D.A. \& Morgan H.W. (1989). $\beta$-Galactosidase from a strain of the anaerobic thermophile, Thermoanaerobacter. Enzyme and Microbial Technology 11(3): 180-186. DOI: https://doi.org/10.1016/0141-0229(89)90079-3

Lu L., Xiao M., Li Z., Li Y. \& Wang F. (2009). A novel transglycosylating $\beta$-galactosidase from Enterobacter cloacae B5. Process Biochemistry 44(2): 232-236. DOI: https://doi.org/10.1016/j.procbio.2008.10.010

Maccaferri S., Klinder A., Brigidi P., Cavina P. \& Costabile A. (2012). Potential probiotic Kluyveromyces marxianus B0399 modulates the immune response in CaCO-2 cells and peripheral blood mononuclear cells and impacts the human gut microbiota in an in vitro colonic model system. Applied and Environmental Microbiology 78(4): 956-964. DOI: https://doi.org/10.1128/AEM.06385-11

Mahoney R.R. \& Adamchuk C. (1980). Effect of milk constituents on the hydrolysis of lactose by lactase from Kluyveromyces fragilis. Journal of Food Science 45(4): 962-964.

DOI: https://doi.org/10.1111/j.1365-2621.1980.tb07487.x

Martarello R.D., Cunha, L., Cardoso S.L., de Freitas M.M., Silveira D., Fonseca-Bazzo Y.M., de Mello M.H., Filho E.X.F. \& Magalhaes P.O. (2019). Optimization and partial purification of $\beta$-galactosidase production by Aspergillus niger isolated from Brazilian soils using soybean residue. AMB Express 9: Article number 81 (2019).

DOI: https://doi.org/10.1186/s13568-019-0805-6

Matioli G., Farias de Moraes F. \& Maria Zanin G. (2001). Hydrolysis of lactose by $\beta$-galactosidase from Kluyveromyces fragilis: characterization of the enzyme. Maringá 23: 655-659.

Miller J.H. (1972). Experiments in Molecular Genetics: Assay of $\beta$-Galactosidase, pp. 352-355. CSH Laboratory Press, Cold Spring Harbor. USA.

Niu D., Tian X., Mchunu N.P., Jia C., Singh S., Liu X., Prior B.A. \& Lu F. (2017). Biochemical characterization of three Aspergillus niger $\beta$-galactosidases. Electronic Jounal of Biotechnology 27: 37-43.

DOI: https://doi.org/10.1016/j.ejbt.2017.03.001

O'Connell S. \& Walsh G. (2008). Application relevant studies of fungal $\beta$-galactosidases with potential application in the alleviation of lactose intolerance. Applied Biochemistry and Biotechnology 149(2): 129-138.

DOI : https://doi.org/10.1007/s12010-007-8098-7

Pal A., Melita L., M. \& Khanum F. (2013). Extraction, purification and thermodynamic characterization of almond (Amygdalus communis) $\beta$-galactosidase for the preparation of delactosed milk. Food Technology and Biotechnology 51(1): 53-61.

Panesar P.S., Kaur R. \& Singh R.S. (2016). Isolation and screening of fungal strains for $\beta$ - isolation and screening of fungal strains for $\beta$-galactosidase production. International Journal of Nutrition and Food Engineering 10(7): 400-404.

Park Y.K., Santi M.S.S. \& Pastore G.M. (1979). Production and characterization of $\beta$-galactosidase from Aspergillus oryzae. Journal of Food Science 44(1): 100-103.

DOI: https://doi.org/10.1111/j.1365-2621.1979.tb10016.x

Princely E.G., Basha S., Kirubakaran J. \& Dhanaraju M.D. (2013). Biochemical characterization, partial purification, and production of an intracellular $\beta$-galactosidase from Streptococcus thermophilus grown in whey. Pelagia Research Library European Journal of Experimental Biology 3(2): 242-251.

Roy I. \& Gupta M.N. (2003). Lactose hydrolysis by lactozym immobilized on cellulose beads in batch and fludized bed modes. Process Biochemistry 39: 325-332. DOI: https://doi.org/10.1016/S0032-9592(03)00086-4

Saad R.R. (2004). Purification and some properties of $\beta$-galactosidase from Aspergillus japonicus. Annals of Microbiology 54(3). 299-306.

Santos F.A.P., Huber J.T., Theurer C.B., Swingle R.S., Simas J.M., Chen K.H. \& Yu P. (1998). Milk yield and composition of lactating cows fed steam-flaked sorghum and graded concentrations of ruminally degradable protein. Journal of Dairy Science 81(1): 215-220. DOI: https://doi.org/10.3168/jds.S0022-0302(98)75568-7

Saqib S., Akram A., Halim S.A. \& Tassadug R. (2017). Sources of $\beta$-galactosidase and its applications in food industry. 3 Biotech 7(1): 79.

DOI: https://doi.org/10.1007/s13205-017-0645-5 
Shaikh S.A., Khire J.M. \& Khan M.A. (1997). Production of $\beta$-galactosidase from thermophilic fungus Rhizomucor sp. Journal of Industrial Microbiology and Bacteriology 19(4): 239-245.

DOI: https://doi.org/10.1038/sj.jim.2900452

Sorensen S.G. \& Crisan E.V. (1974). Thermostable lactase from thermophilic fungi. Journal of Food Science 39(6): 1184-1187.

DOI: https://doi.org/10.1111/j.1365-2621.1974.tb07349.x

Soydan M. (2006). Production of thermosatable $\beta$-galactosidase from thermophilic fungi for use in low lactose milk production. MSc thesis. Middle East Technical University, Ankara, Turkey.

Tanaka T., Kagamiishi A., Kiuchi A. \& Horiuchi T. (1975). Purification and properties of $\beta$-galactosidase from Aspergillus oryzae. The Journal of Biochemistry 77(1): 241-247.

DOI: https://doi.org/10.1093/oxfordjournals.jbchem.a130713

Todorova-Balvay D., Stoilova I., Gargova S. \& Vijaylakshmi M.A. (2006). An efficient two step purification and molecular characterization of $\beta$-galactosidases from
Aspergillus oryzae. Journal of Molecular Recognition 19(4): 299-304.

DOI: https://doi.org/10.1002/jmr.788

Wingfield P.T. (2001). Protein precipitation using ammonium sulfate. Current Protocols in Protein Science 80: 6.1.16.1.35.

DOI: https://doi.org/10.1002 / 0471140864.ps0601s80

Xu X., Fan X., Fan C., Qin X., Liu B., Nie C., Sun N., Yao Q., Zhang Y. \& Zhang W. (2019). Production optimization of an active $\beta$-galactosidase of Bifidobacterium animalis in heterologous expression systems. BioMed Research International 2019: 1-10.

DOI: https://doi.org/10.1155/2019/8010635

Zadow J.G. (1992). Lactose hydrolysis. In: Whey and Lactose Processing (ed. J.G. Zadow), pp 361. Elsevier Applied Sciences, London and NewYork.

Zhou Q.Z. \& Chen X.D. (2001). Effects of temperature and $\mathrm{pH}$ on the catalytic activity of the immobilized $\beta$-galactosidase from Kluyveromyces lactis. Biochemical Engineering Journal 9(1): 33-40.

DOI : https://doi.org/10.1016/S1369-703X(01)00118-8 